\title{
Quality of bulk tank milk samples from Danish dairy herds based on real-time polymerase chain reaction identification of mastitis pathogens
}

\author{
J. Katholm, ${ }^{\star 1}$ T. W. Bennedsgaard, $†$ M. T. Koskinen, $\neq$ and E. Rattenborg ${ }^{*}$ \\ *Knowledge Center for Agriculture, Cattle, Skejby, DK-8200 Aarhus N, Denmark \\ †Institute of Animal Sciences, Aarhus University, DK-8830 Tjele, Denmark \\ $\ddagger$ Thermo Fisher Scientific, Microbiology Division, 01620 Vantaa, Finland
}

\section{ABSTRACT}

Results of a commercial real-time PCR analysis for 11 mastitis pathogens from bulk tank milk (BTM) samples from all 4,258 Danish dairy herds in November 2009 to January 2010 were compared with somatic cell count (SCC) and total bacteria count (TBC) estimates in BTM. For Streptococcus agalactiae, Streptococcus dysgalactiae, and Streptococcus uberis, a low real-time $\mathrm{PCR}$ cycle threshold $(\mathrm{Ct})$ value (corresponding to high bacterial DNA quantity) was correlated with higher SCC and higher TBC. For Staphylococcus aureus, low $\mathrm{Ct}$ values were correlated only with higher SCC. For the environmental mastitis pathogens Klebsiella spp., Enterococcus spp., and Escherichia coli, low Ct values had a correlation with higher TBC. Staphylococcus spp. were found in the BTM from all herds, Strep. uberis in $95 \%$, Staph. aureus in 91\%, and Strep. dysgalactiae in $86 \%$, whereas E. coli, Klebsiella, and Strep. agalactiae were found in 61,13 , and $7 \%$ of the herds. It is concluded that the real-time PCR used provides results that are related to the milk quality in the herds. Realtime PCR can be used in the same way as culture for monitoring BTM samples, and is especially useful for bacteria with low prevalence (e.g., Strep. agalactiae).

Key words: real-time polymerase chain reaction, bulk tank milk, milk quality, Streptococcus agalactiae

\section{INTRODUCTION}

Mastitis is the most common and costly contagious disease affecting dairy farms in the western world (Barkema et al., 2009). Bulk milk SCC (BTSCC) is routinely considered an indicator of subclinical mastitis in dairy herds. In Denmark, BTSCC and treatment frequency are the 2 main parameters for monitoring the overall mastitis situation in the country. Bacterial culture-based identification of mastitis pathogens other than Streptococcus agalactiae from bulk tank samples

Received December 29, 2011.

Accepted June 17, 2012.

${ }^{1}$ Corresponding author: jka@vfl.dk is currently not used in Denmark. Danish veterinarians routinely use bacterial culture of quarter milk samples to improve mastitis management and to guide treatment; it remains unclear whether an annual screening program for all main mastitis pathogens would be useful. In contrast, bulk tank culture is widely accepted in many other countries as a useful tool for evaluating the quality of milk and monitoring udder-health status in a herd (Jayarao and Wolfgang, 2003; Barkema et al., 2009). Several studies have shown a correlation between mastitis pathogens in the bulk tank milk (BTM) and BTSCC and total bacteria count (TBC; Erskine et al., 1987; Keefe et al., 1997; Phuektes et al., 2003; Zadoks et al., 2004; Ryšánek et al., 2009).

Since 1963, Denmark has had a continuous surveillance program for Strep. agalactiae. The program involves annual Strep. agalactiae testing of BTM from all herds using conventional bacterial culture. Culturepositive herds are recorded in a public database, which serves as a tool for dairy farmers who are buying cattle. Although this program has been useful for measuring the overall prevalence of Strep. agalactiae, it has not helped to control the incidence of infections; instead, from the year 2000 onward, Strep. agalactiae prevalence has increased considerably from less than $2 \%$ before year 2000 to $6.1 \%$ of all Danish dairy herds in 2009 (Katholm, 2010).

Bacterial culture of milk samples on blood agar plates has for many years been the standard method for identification of mastitis pathogens. The sensitivity of culture of Strep. agalactiae from bulk milk samples is commonly debated. Depending on the culture media used, the inoculum volumes applied, and the specific design of different studies, the sensitivity of detecting Strep. agalactiae from BTM varies between 20.5 and $78 \%$ (Keefe, 1997). Because the sensitivity of a single bulk milk culture is limited, longitudinal monitoring is necessary to achieve high herd-level sensitivity of pathogen detection (Fox et al., 2005; Olde Riekerink et al., 2006).

Molecular methods have been suggested to improve the sensitivity of intramammary pathogen detection 
since the 1990s (e.g., Oliver et al., 1998; Marcos et al., 1999; Koskinen et al., 2010). In particular, PCR-based methods are increasingly being used in mastitis diagnostics. For example, Koskinen et al. (2010) compared PCR and culture using 1,000 milk samples from cows with clinical and subclinical mastitis and from healthy cows and concluded that PCR provided higher sensitivity than culture for the detection of several bacteria.

The objective of this study was to investigate the prevalence of 11 IMI pathogens as well as the $\beta$-lactamase penicillin resistance gene in BTM by using a PCR test. Further, our aim was to evaluate milk quality parameters in BTSCC and bulk tank TBC in relation to $\mathrm{PCR}$ results for mastitis pathogens.

\section{MATERIALS AND METHODS}

\section{Samples and Logistics}

Bulk tank milk samples from all dairy herds registered in Denmark as of December 31, 2009, were included in the study $(\mathrm{n}=4,258)$. The average herd size and milk production in Denmark in 2009 was 121 cows and 9,022 $\mathrm{kg}$ of ECM/cow per year (Danish Dairy Board, 2011).

One sample was collected from each herd for bacterial culture and PCR testing between October 20, 2009, and January 6, 2010. Bulk tank milk sampling was performed during normal milk collection using a VM OVP sampling device (VM Tarm A/S, Tarm, Denmark). The collection device excluded the first 30 to 40 $\mathrm{L}$ of milk and thereafter sampled $1.5 \mathrm{~mL}$ for 40 times at regular intervals, delivering a final sample volume of 60 $\mathrm{mL}$. In the last step, the device was cleaned with pressurized air. The samples were immediately stored on ice and delivered to Eurofins Steins Laboratorium A/S (Holstebro, Denmark) within $24 \mathrm{~h}$. Samples for TBC and BTSCC were collected by the same procedure. According to the Danish milk quality program, TBC was measured once every second week in all herds. Bulk tank SCC was measured at each delivery (daily or every second day) in most herds and once a week for $9.4 \%$ of the herds. The samples used for TBC and BTSCC in this study were the latest ordinary samples tested. The time between sampling for PCR testing and TBC varied between 0 and $12 \mathrm{~d}$, with $42 \%$ of the samples within $2 \mathrm{~d}$ and $83 \%$ within $6 \mathrm{~d}$. Bulk tank SCC was measured on the same day as the PCR testing in $90.6 \%$ of the herds and within $4 \mathrm{~d}$ from the PCR testing in the rest of the herds.

\section{Milk Quality Testing}

Bulk tank SCC was measured by flow cytometry using a Fossomatic 5000 instrument (Foss, Hillerød,
Denmark). Total bacteria count was measured by flow cytometry using a Bactocount instrument (Bentley Instruments, Chaska, MN) calibrated to provide results comparable with the standard plate count. The results were recorded in the Danish Cattle Database.

\section{Microbial Testing Procedures}

The samples were tested for 11 mastitis pathogens and the staphylococcal $\beta$-lactamase gene blaZ (responsible for penicillin resistance in staphylococci) by using real-time PCR (PathoProof Mastitis PCR Assay, Thermo Fisher Scientific, Vantaa, Finland). The PCR test was used for direct DNA extraction and real-time PCR (i.e., without any culture procedures). The test took approximately $4 \mathrm{~h}$ from start to finish. A total of $350 \mu \mathrm{L}$ of milk was used as a starting volume for DNA extraction. The DNA extraction protocol involved an enzymatic lysis step, disrupting the cell walls of grampositive and gram-negative bacteria, as well as spin column-based DNA purification and elution steps. Before scoring any given reaction as negative, acceptable PCR conditions were always confirmed by verifying that the cycle threshold $(\mathbf{C t})$ values and the shape of the amplification curves of the internal amplification controls were acceptable (see Koskinen et al., 2009, for further information). A negative control (distilled $\mathrm{H}_{2} \mathrm{O}$ ) was included in every real-time PCR run for confirmation that cross-contamination had not occurred in the laboratory. All additional protocol details were identical to those described elsewhere (Koskinen et al., 2009; Taponen et al., 2009).

The Ct values obtained were recorded for all samples. The $\mathrm{Ct}$ value is the measurement used for analyzing real-time PCR results. It represents the number of PCR cycles required to reach a set threshold fluorescence signal level. The fewer cycles it takes to obtain the threshold level, the greater the amount of template DNA in the sample. Because PCR amplification of the assay proceeds in a manner whereby DNA approximately doubles in each cycle, a $\mathrm{Ct}$ difference of, for example, 1 between any 2 samples corresponds to a $2 \times$ difference in the bacterial DNA amount in the samples.

For samples positive for Strep. agalactiae in culture but negative in PCR, part of the microbial 16S rRNA gene was sequenced if a pure culture could be obtained (17 out of 20 samples). The PCR products were purified using a QIAquick PCR Purification Kit (Qiagen Inc., Valencia, CA) and sequenced at MWG Biotech (Ebersberg, Germany). Satisfactory quality of each sequencing electropherogram was confirmed visually. The nucleotide sequences were compared with GenBank sequences using the Basic Local Alignment Search Tool. Pair-wise sequence alignments were performed using 
the program DNA Star (DNASTAR Inc., Madison, WI).

\section{Statistical Methods}

Descriptive Statistics. Descriptive statistics for the distribution of $\mathrm{Ct}$ values were calculated for each bacterial gene. The proportion of herds with a positive reaction $(\mathrm{Ct}<40)$ was calculated, and the mean value, standard deviation, and distribution of the values for herds with positive results $(\mathrm{Ct}<40)$ were calculated.

Statistical Analyses. The correlations between Ct values for the different bacterial DNA and BTSCC and TBC were analyzed. First, a generalized additive model was made using PROC GAM in SAS version 9.3 (SAS Institute Inc., Cary, NC) to explore changes in correlation with changing $\mathrm{Ct}$ values. The curve fitted by the GAM model was plotted together with the raw $\mathrm{Ct}$ values to get an idea of the best model for a possible correlation. For all pathogens in which a correlation was seen, a linear correlation for $\mathrm{Ct}$ values below a certain breakpoint and a constant value above the breakpoint seemed to be the best model. The breakpoint of the curve was different for the different pathogens. The breakpoint was established based on PROC GAM, and $\mathrm{Ct}$ values above the breakpoint were included separately in the model by using a piecewise regression model. Models including both untransformed and log-transformed BTSCC and TBC were tested to identify the best models. The preceding BTSCC without logarithmic transformation was used as the outcome in the linear regression model. A logarithmic transformation of the preceding $\mathrm{TBC}$ was used as the outcome for the linear regression model. The correlations between BTSCC and TBC and the PCR reaction were determined using a linear mixed model that included all bacterial genes with a significant effect $(P=0.05)$ on the outcome variable. The pathogens of most interest (Staphylococcus aureus, Strep. agalactiae, Streptococcus dysgalactiae, Streptococcus uberis, and Escherichia coli) were kept in the model even in case of nonsignificant effects.

To evaluate the effect of Strep. agalactiae in BTM on the risk of TBC above the milk quality thresholds of $30,000,50,000$ and $100,000 \mathrm{cfu} / \mathrm{mL}$, data on TBC from a period of $180 \mathrm{~d}$ before the PCR test was analyzed. The prevalence of TBC above the limits was calculated for herds with a PCR reaction at $\leq 32$ or $>32$ for Strep. agalactiae, and the difference was tested by a $t$-test using PROC TTEST in SAS version 9.3 (SAS Institute Inc.). The $\mathrm{Ct}$ value of 32 was chosen based on the breakpoint for analysis of the effect of PCR reaction for Strep. agalactiae on TBC.

\section{RESULTS}

\section{Real-Time PCR Analysis}

Descriptive statistics of the $\mathrm{Ct}$ values for all $12 \mathrm{PCR}$ targets are presented in Table 1. All the species detected by the PCR assay were commonly found in the BTM of Danish dairy herds, except Strep. agalactiae (found in $7 \%$ of the samples), Klebsiella (13\%), and Serratia marcescens (2\%). The only species found in all herds were Staph. spp. The major contagious mastitis pathogens and Strep. uberis had low median values (29.8 to 31.6) for positive herds compared with bacteria considered common environmental bacteria ( $E$. coli, Enterococcus spp., Klebsiella spp., S. marcescens; median 33.7 to 37.8 ).

\section{Ct Values and BTM Quality}

The breakpoints for the correlation between $\mathrm{Ct}$ value and BTSCC were decided as 28 for E. coli, 32 for Strep. agalactiae and Strep. dysgalactiae, 33.5 for Staph. aureus, and 34.5 for Strep. uberis. Selected graphs show the correlation for Strep. agalactiae, Strep. dysgalactiae, Staph. aureus, Strep. uberis, and E. coli in Figure 1. The effect of E. coli on BTSCC was not significant but was kept in the model to show its lack of importance. Removing $E$. coli from the model had a marginal effect on the estimates for the other bacteria in the model. The baseline BTSCC was estimated to 184,562 cells/ $\mathrm{mL}$ and the BTSCC increased with a decrease in the Ct value, with 10,389, 9,074, 4,178, and 3,707 cells/mL per 1-unit change in Ct below the breakpoints for Staph. aureus, Strep. uberis, Strep. dysgalactiae, and Strep. agalactiae, respectively.

The breakpoints for the correlation between $\mathrm{Ct}$ value and TBC were decided as 30.5 for Staph. aureus, 32 for Strep. agalactiae, 32 for Strep. dysgalactiae, and 35 for Strep. uberis. For E. coli, Enterococcus spp., and Klebsiella spp., the breakpoint was 40. Selected graphs showing the correlations are presented for Strep. agalactiae, Strep. dysgalactiae, Staph. aureus, Strep. uberis, Enterococcus spp., E. coli, and Klebsiella spp. in Figure 2. The effect of Staph. aureus on TBC was not significant but was kept in the model to show its lack of importance. The baseline TBC was estimated to $7,508 \mathrm{cfu} / \mathrm{mL}$, and the TBC increased with decreasing $\mathrm{Ct}$ values for the bacteria presented. The prevalence values of TBC above the Danish milk quality threshold of $30,000,50,000$, and $100,000 \mathrm{cfu} / \mathrm{mL}$ were higher in herds with a Strep. agalactiae Ct value at or below 32 (Table 2). 
Table 1. Results of a real-time PCR test ${ }^{1}$ of bulk tank milk samples in 4,258 Danish dairy herds sampled from October 2009 to January 2010

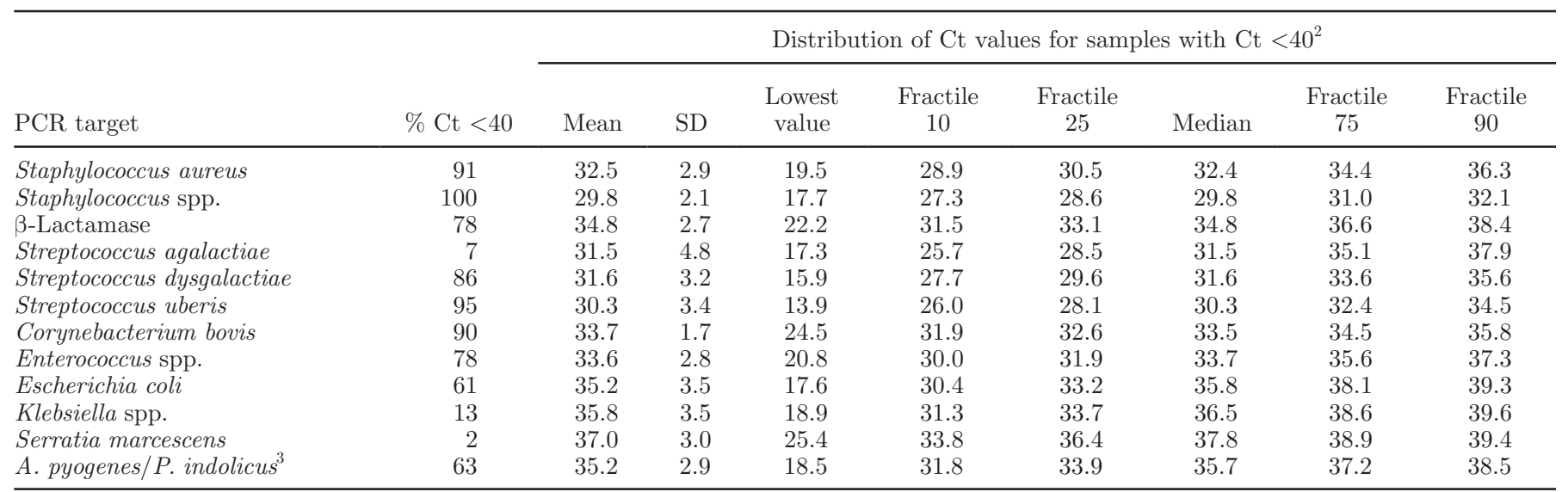

${ }^{1}$ PathoProof Mastitis PCR Assay (Thermo Fisher Scientific, Vantaa, Finland).

${ }^{2} \mathrm{Ct}=40$ is regarded as a negative test. $\mathrm{Ct}=$ cycle threshold.

${ }^{3}$ A. pyogenes/P. indolicus: Arcanobacterium pyogens/Peptococcus indolicus.

\section{DISCUSSION}

\section{Prevalence of Pathogens}

Monitoring of major mastitis pathogens in BTM at the population level has been described in only a few studies. Ryšánek et al. (2009) sampled 268 randomly selected herds. The prevalence by culture was $19 \%$ for Enterococcus spp. (E. faecium and E. faecalis), $14 \%$ for Strep. uberis, $13 \%$ for Strep. dysgalactiae, $12 \%$ for Staph. aureus, $7 \%$ for E. coli, and $3 \%$ for Strep. agalactiae.
In a study in all 258 herds on Prince Edward Island, Canada, 3 consecutive BTM samples were cultured at weekly intervals. Cumulative prevalence values of Staph. aureus and Strep. agalactiae were 74 and 1.6\%, respectively (Olde Riekerink et al., 2006). Zadoks et al. (2004) cultured BTM samples from 48 New York State dairy herds and found $31 \%$ positive for Strep. agalactiae and $81 \%$ positive for Strep. uberis. Phuektes et al. (2003) tested BTM from 42 herds in Australia on 5 occasions at approximately 10-d intervals with a multiplex PCR. The herds were selected based on low,

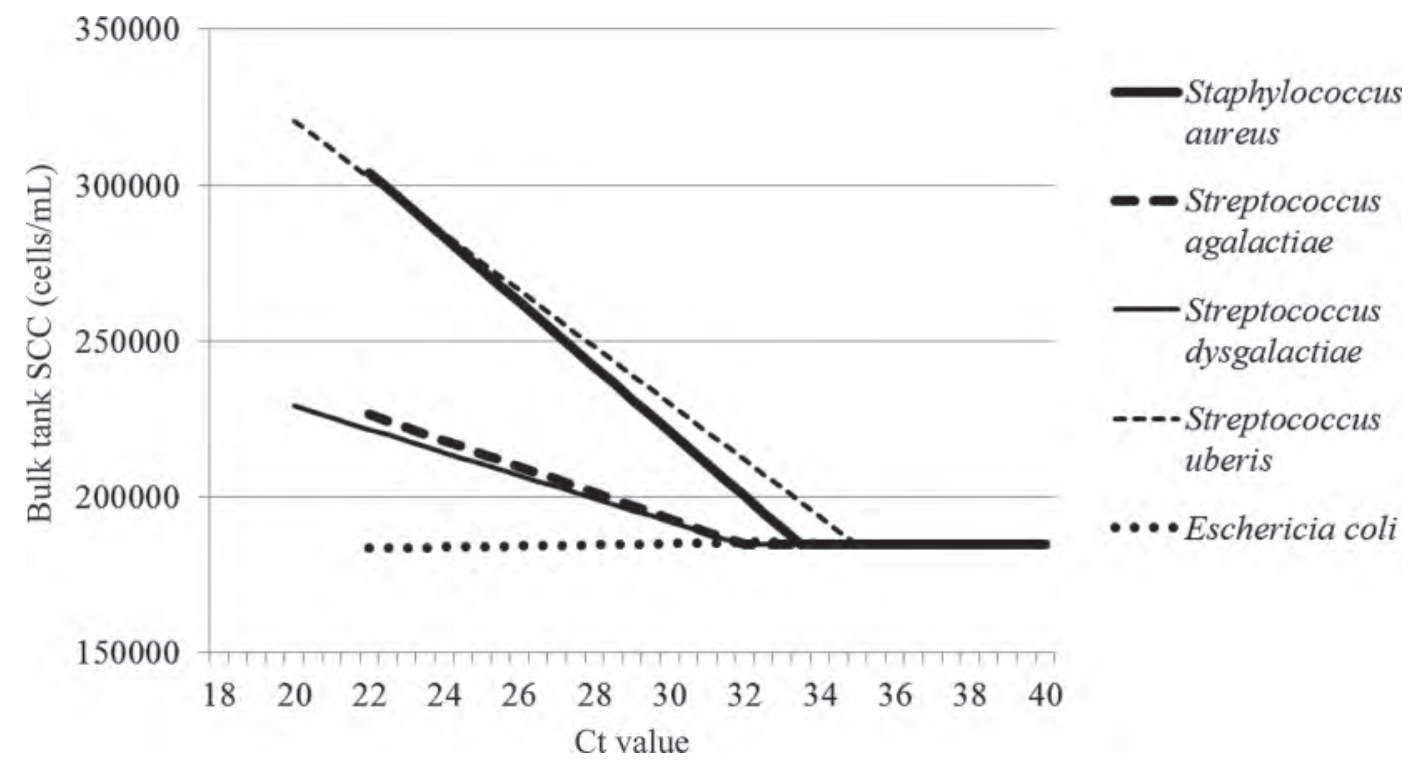

Figure 1. Correlation between cycle threshold (Ct) values of real-time PCR (PathoProof Mastitis PCR Assay, Thermo Fisher Scientific, Vantaa, Finland) for different bacteria and bulk tank SCC estimated from a linear mixed model. The effect of Escherichia coli was not different from zero. 
Table 2. Herd prevalence (\%; $95 \%$ CI in parentheses) of total bacteria count in bulk tank milk above the limits of 30,000,50,000, and 100,000 $\mathrm{cfu} / \mathrm{mL}$ the last $180 \mathrm{~d}$ before bulk tank milk PCR testing in 4,258 Danish dairy herds with a cycle threshold $(\mathrm{Ct})$ value above or below 32 for Streptococcus agalactiae

\begin{tabular}{lcc}
\hline & \multicolumn{2}{c}{ Ct value for Strep. agalactiae } \\
\cline { 2 - 3 } $\begin{array}{l}\text { Total bacteria } \\
\text { count }(\mathrm{cfu} / \mathrm{mL})\end{array}$ & $\leq 32$ & $>32$ \\
\hline$>30,000$ & $12.1^{\mathrm{a}}(9.6-14.6)$ & $7.3^{\mathrm{b}}(6.8-7.7)$ \\
$>50,000$ & $5.5^{\mathrm{a}}(4.2-6.9)$ & $3.3^{\mathrm{b}}(3.1-3.6)$ \\
100,000 & $2.2^{\mathrm{a}}(1.4-3.0)$ & $1.5^{\mathrm{b}}(1.3-1.6)$ \\
\hline
\end{tabular}

${ }^{\mathrm{a}, \mathrm{b}}$ Different letters within a row indicate significant differences $(P=$ $0.05)$.

medium, or high BTSCC. They found Strep. uberis in at least 1 of the 5 samples in $83 \%$, Strep. dysgalactiae in $55 \%$, Staph. aureus in $33 \%$, and Strep. agalactiae in $26 \%$ of the herds. If Strep. agalactiae was detected by $\mathrm{PCR}$, it was constantly detected in repeated samples collected from the herd. Compared with the referenced studies, the prevalence values of Staph. aureus and Strep. dysgalactiae were high in the Danish herds. The higher prevalence of these udder-specific bacteria might be influenced by the limited use of dry cow treatments in Danish herds because of legislation prohibiting the use of dry cow antibiotics without a microbiological diagnosis or clinical mastitis (Danish Veterinary and Food Administration, 2010). The prevalence of Strep. agalactiae was low compared with the results from New
York state and Australia but high compared with the Canadian study. In Denmark, Strep. agalactiae has been regulated by a mandatory annual surveillance with registration of infected herds and restrictions against the sale of livestock, but has been increasing from approximately $2 \%$ in 2000 to the current level of $6.1 \%$ in 2009 (Katholm, 2010). In addition, other Nordic countries have reported similar problems. In Sweden, $4.9 \%$ of BTM samples from 465 herds with automatic milking systems were found to be positive for Strep. agalactiae; in Norway, 3.3\% of BTM samples from 936 larger herds (more than 35 cows) were positive for Strep. agalactiae; and on Faroe Island, 7 herds $(23 \%)$ were positive for Strep. agalactiae in a test of BTM from all 30 dairy herds in 2010. All 3 investigations were performed using the PathoProof PCR test (Katholm, 2010).

The low median Ct value for major contagious mastitis pathogens (Strep. agalactiae, Strep. dysgalactiae, Staph aureus) compared with the median values of $E$. coli, Enterococcus spp., and Klebsiella spp. might be a result of subclinically infected cows shedding bacteria in high numbers, which, in herds with a high prevalence of the bacteria, results in very high numbers of bacteria in the BTM. These environmental bacteria would be shed for only a short time by cows with clinical mastitis, and most bacteria in the milk and their presence in BTM are suggestive of problems related to stall management, udder hygiene, and milking practices, resulting in con-

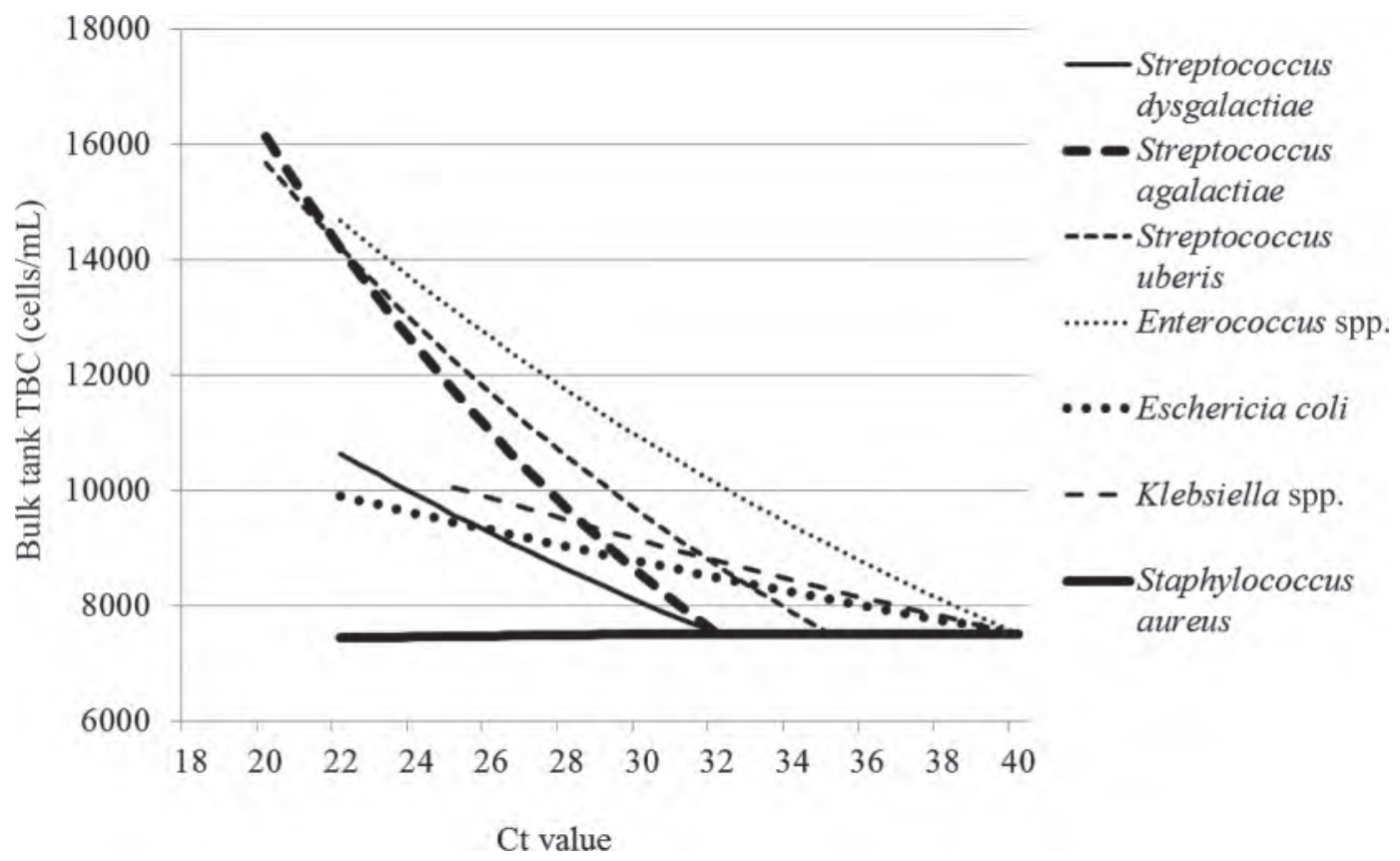

Figure 2. Correlation between cycle threshold $(\mathrm{Ct})$ values of real-time PCR (PathoProof Mastitis PCR Assay, Thermo Fisher Scientific, Vantaa, Finland) for different bacteria and bulk tank total bacterial counts (TBC) estimated from a linear mixed model. The effect of Staphylococcus aureus was not different from zero. 
tamination of the milk (Jayarao and Wolfgang, 2003; Hogan and Smith, 2012).

\section{PCR as an Indicator of Milk Quality}

Analysis of the association between BTSCC and $\mathrm{TBC}$ and the $\mathrm{Ct}$ values (Figures 1 and 2) estimates the influence of the different bacteria on milk quality. The difference regarding the $\mathrm{Ct}$ value for different bacteria might be a result of E. coli and Enterococcus spp. acting as indicator bacteria, representing general hygiene problems in the herds resulting in contamination of the milk in the bulk tank, with many different bacteria all accounting for the TBC, whereas the effect of the more udder-specific bacteria, such as Strep. uberis and Strep. agalactiae on TBC might be the result of the specific bacteria being shed from infected quarters in very high numbers. Streptococcus uberis had a high threshold value of 35 , which might be a result of the bacteria being shed from infected cows but also being an environmental species present in high numbers in herds with poor hygiene. We found no significant correlation between Staph. aureus Ct value and TBC. Staphylococcus aureus is not thought to be a frequent contributor to TBC (Gonzalez et al., 1986; Jeffrey and Wilson, 1987; Fenlon et al., 1995).

In general, the environmental mastitis bacteria, including Enterococcus spp., E. coli, and Klebsiella, had high median Ct values in positive herds compared with the contagious mastitis pathogens, indicating that they were found in lower numbers. In cases with high $E$. coli $\mathrm{Ct}$ values, the BTSCC was generally not affected. This is not surprising because E. coli udder infections normally are of short duration and often the milk will be visibly changed and subsequently discarded and not entering the bulk tank. Enterococcus spp. are rarely found to be the primary cause of mastitis and are not expected to cause prolonged udder infection with elevated cell counts.

For the other major mastitis pathogens, the correlation between $\mathrm{Ct}$ values and BTSCC was strongest for Staph. aureus and Strep. uberis. These 2 species are the main causes of high SCC, based on our results. This result is in agreement with other studies with culture of milk samples from both clinical cases and cross-sectional sampling (Barkema et al., 1998; Jayarao et al., 2004; Ryšánek et al., 2009). The Ct values for Strep. dysgalactiae were at the same level as those of Staph. aureus, but the effect on the BTSCC was much less (approximately 50\%). Streptococcus agalactiae also had a significant effect on the BTSCC but was found in only $7 \%$ of the herds, which is in accordance with other studies (Erskine et al., 1987; Keefe et al., 1997; Phuektes et al., 2003).
The Ct values for Corynebacterium bovis (Table 1) were characterized by a very low standard deviation and a median at 34. Although it could be expected to be a potential indicator for low udder hygiene, the low standard deviation makes it of little value for characterization of the herds.

\section{BTM Bacteria and Milk Quality}

Bacteriological testing of raw BTM is used as an indicator of udder health, milk harvest hygiene, and storage conditions on the farm. Our TBC results might have been affected by the fact that TBC was not necessarily measured on the same day as the samples for PCR. The difference in sampling times might result in an underestimation of the effect of the different bacteria. The effect of the udder-specific mastitis pathogens, such as Strep. agalactiae, on TBC is probably related to the excretion of bacteria in high numbers from both acute and chronic cases. Streptococcus agalactiae and Strep. uberis have been found to be shed in very high numbers (up to $10^{9}$ bacteria/mL from infected quarters; Guterbock and Blackmer 1984; Schukken et al., 2011).

The higher prevalence of TBC above 30,000, 50,000, and $100,000 \mathrm{cfu} / \mathrm{mL}$ in herds with a Strep. agalactiae Ct value $\leq 32$ (Table 2 ) is in accordance with the correlation between $\mathrm{Ct}$ values and TBC (Figure 2). Accordingly, Keefe et al. (1997) found that herds infected with Strep. agalactiae were 5.48 times more likely to be penalized for a high standard plate count. Our results are also in agreement with those of Jeffrey and Wilson (1987), who found that $28.1 \%$ of all failed TBC tests were caused by more than $90 \%$ of mastitis bacteria present in the milk. Streptococcus uberis accounted for $50 \%$ of the cases and Strep. agalactiae accounted for $33 \%$ of the cases.

For Strep. agalactiae, a correlation between the proportion of shedding cows and TBC has previously been shown to exist in many but not all herds, and discrepancies between the proportion of shedding cows and counts in BTM was attributed to variation in levels of shedding among cows (Gonzalez et al., 1986; Farnsworth, 1993). Zadoks et al. (2004) concluded that infected cows were the source of Strep. uberis in raw BTM because the bacteria in the bulk tank was of the same strain as the bacteria in infected cows.

Repeated sampling of BTM is needed to determine a true prevalence estimate of contagious mastitis pathogens (Godkin and Leslie, 1993; Ruegg and Reinemann, 2002). Therefore, we expect that repeated sampling of BTM will provide yet more precise estimations of the role of the different pathogens. This will be evaluated in future investigations. 


\section{CONCLUSIONS}

Real-time PCR for mastitis bacteria in BTM can be used in the same way as culture for monitoring BTM samples, especially for bacteria with low prevalence (e.g., Strep. agalactiae).

We have presented baseline figures for 11 mastitis pathogens and the $\beta$-lactamase gene in BTM samples from all Danish dairy herds in 2009. High levels of mastitis bacteria are related to decreased milk quality. We found that high PCR-based quantities (low Ct values) of Staph. aureus, Strep. uberis, Strep. dysgalactiae, and Strep. agalactiae correlated with high BTSCC and that low PCR-based quantities (high Ct values) of Strep. agalactiae, Strep. uberis, Enterococcus spp., Strep. dysgalactiae, E. coli, and Klebsiella spp. correlated with high TBC.

\section{REFERENCES}

Barkema, H. W., M. J. Green, A. J. Bradley, and R. N. Zadoks. 2009. Invited review: The role of contagious diseases in udder health. J. Dairy Sci. 92:4717-4729.

Barkema, H. W., Y. H. Schukken, T. J. G. M. Lam, M. L. Beloher, H. Wilmink, G. Benedictus, and A. Brand. 1998. Incidence of clinical mastitis in dairy herds grouped in three categories by bulk milk somatic cell counts. J. Dairy Sci. 81:411-419.

Danish Dairy Board. 2011. Mejeristatistik, Dairy Statistics. August 2011. Danish Dairy Board, Viby, Denmark. Accessed Jun. 1, 2012. http://www.lf.dk/Tal_og_Analyser/Aarstatistikker/Mejeristatistik/ /media/lf/Tal\%20og\%20analyser/Aarsstatistikker/Mejeristatistik/2010/Mejeristatistik\%202010.ashx.

Danish Veterinary and Food Administration. 2010. Bek. nr. 785 af 25/06/2010 Bekendtgørelse om dyrlægers anvendelse og udlevering og ordinering af lægemidler til dyr. Accessed Jun. 1, 2012. https:// www.retsinformation.dk/Forms/R0710.aspx?id $=132613$.

Erskine, R. J., R. J. Eberhart, L. J. Hutchinson, and S. B. Spencer. 1987. Herd management and prevalence of mastitis in dairy herds with high and low somatic cell counts. J. Am. Vet. Med. Assoc. 190:1411-1416.

Farnsworth, R. J. 1993. Microbiologic examination of bulk tank milk. Vet. Clin. North Am. Food Anim. Pract. 9:469-474.

Fenlon, D. R., D. N. Logue, J. Gunn, and J. Wilson. 1995. A study of mastitis bacteria and herd management practices to identify their relationship to high somatic cell counts in bulk tank milk. Br. Vet. J. 151:17-25.

Fox, L. K., J. H. Kirk, and A. Bitten. 2005. Mycoplasma mastitis: A review of transmission and control. J. Vet. Med. B Infect. Dis. Vet. Public Health 52:153-160.

Godkin, M. A., and K. E. Leslie. 1993. Culture of bulk tank milk as a mastitis screening test: A brief review. Can. Vet. J. 34:601-605.

Gonzalez, R. N., D. E. Jasper, R. B. Bushnell, and T. B. Farver. 1986. Relationship between mastitis pathogen numbers in bulk tank milk and bovine udder infections in California dairy herds. J. Am. Vet. Med. Assoc. 189:442-445.

Guterbock, W. M., and P. E. Blackmer. 1984. Veterinary interpretation of bulk-tank milk. Vet. Clin. North Am. Large Anim. Pract. $6: 257-268$.

Hogan, J., and K. L. Smith. 2012. Managing environmental mastitis. Vet. Clin. North Am. Food Animal. Pract. http://dx.doi.org/ $28: 217-224$.
Jayarao, B. M., S. R. Pillai, A. A. Sawant, D. R. Wolfgang, and N. V. Hegde. 2004. Guidelines for monitoring bulk tank milk somatic cell count and bacterial counts. J. Dairy Sci. 87:3561-3573.

Jayarao, B. M., and D. R. Wolfgang. 2003. Bulk-tank milk analysis. A useful tool for improving milk quality and herd udder health. Vet. Clin. North Am. Food Anim. Pract. 19:75-92.

Jeffrey, D. C., and J. Wilson. 1987. Effect of mastitis-related bacteria on total bacterial count of bulk milk supplies. Int. J. Dairy Technol. 40:23-26.

Katholm, J. 2010. Streptococcus agalactiae in the Nordic countries. Pages 11-12 in Proc. Veterinärkongressen, Uppsala, Sweden.

Keefe, G. P. 1997. Streptococcus agalactiae mastitis: A review. Can. Vet. J. 38:429-437.

Keefe, G. P., I. R. Dohoo, and E. Spangler. 1997. Herd prevalence and incidence of Streptococcus agalactiae in the dairy industry of Prince Edward Island. J. Dairy Sci. 80:464-470.

Koskinen, M. T., J. Holopainen, S. Pyorala, P. Bredbacka, A. Pitkala, H. W. Barkema, R. Bexiga, J. Roberson, L. Solverod, R. Piccinini, D. Kelton, H. Lehmusto, S. Niskala, and L. Salmikivi. 2009. Analytical specificity and sensitivity of a real-time polymerase chain reaction assay for identification of bovine mastitis pathogens. J. Dairy Sci. 92:952-959.

Koskinen, M. T., G. J. Wellenberg, O. C. Sampimon, J. Holopainen, A. Rothkamp, L. Salmikivi, W. A. van Haeringen, T. J. G. M. Lam, and S. Pyörälä. 2010. Field comparison of real-time polymerase chain reaction and bacterial culture for identification of bovine mastitis bacteria. J. Dairy Sci. 93:5707-5715.

Marcos, J. Y., A. C. Soriano, M. S. Salazar, C. H. Moral, S. S. Ramos, M. S. Smeltzer, and G. N. Carrasco. 1999. Rapid identification and typing of Staphylococcus aureus by PCR-restriction fragment length polymorphism analysis of the aroA gene. J. Clin. Microbiol. 37:570-574.

Olde Riekerink, R. G., H. W. Barkema, S. Veenstra, D. E. Poole, R. T. Dingwell, and G. P. Keefe. 2006. Prevalence of contagious mastitis pathogens in bulk tank milk in Prince Edward Island. Can. Vet. J. $47: 567-572$.

Oliver, S. P., B. E. Gillespie, and B. M. Jayarao. 1998. Detection of new and persistent Streptococcus uberis and Streptococcus dysgalactiae intramammary infections by polymerase chain reaction based DNA fingerprinting. FEMS Microbiol. Lett. 160:69-73.

Phuektes, P., G. F. Browning, G. Anderson, and P. D. Mansell. 2003. Multiplex polymerase chain reaction as a mastitis screening test for Staphylococcus aureus, Streptococcus agalactiae, Streptococcus dysgalactiae and Streptococcus uberis in bulk milk samples. J. Dairy Res. 70:149-155.

Ruegg, P. L., and D. J. Reinemann. 2002. Milk quality and mastitis tests. Bovine Pract. 36:41-54.

Ryšánek, D., M. Zouharová, and V. Babák. 2009. Major mammary pathogens as contributors to total bacterial counts in raw milk. Acta Vet. (Brno) 78:455-461.

Schukken Y. H., J. Günther, J. Fitzpatrick, M. C. Fontaine, L. Goetze, O. Holst, J. Leigh, W. Petzl, H. -J. Schuberth, A. Sipka, D. G. E. Smith, R. Quesnell, L. Watts, R. Yancey, H. Zerbe, A. Gurjar, R. N. Zadoks, H. -M. Seyfert, Pfizer Mastitis Research Consortium. 2011. Host-response patterns of intramammary infections in dairy cows. Vet. Immunol. Immunopathol. 144:270-289.

Taponen, S., L. Salmikivi, H. Simojoki, M. T. Koskinen, and S. Pyörälä. 2009. Real-time polymerase chain reaction-based identification of bacteria in milk samples from bovine clinical mastitis with no growth in conventional culturing. J. Dairy Sci. 92:26102617.

Zadoks, R. N., R. N. Gonzalez, K. J. Boor, and Y. H. Schukken. 2004. Mastitis-causing streptococci are important contributors to bacterial counts in raw bulk tank milk. J. Food Prot. 67:2644-2650. 